\title{
THE BIVALVE CUNEAMYA FROM THE LATE ORDOVICIAN OF BOHEMIA
}

\author{
MARIKA POLECHOVÁ \\ Czech Geological Survey, Klárov 3, 11843 Prague 1, the Czech Republic; e-mail: marika.polechova@geology.cz.
}

Polechová, M. (2019): The bivalve Cuneamya from the Late Ordovician of Bohemia. - Fossil Imprint, 75(1): 120-127, Praha. ISSN 2533-4050 (print), ISSN 2533-4069 (on-line).

\begin{abstract}
The bivalve species Cuneamya catilloides from the Late Ordovician of Bohemia, previously assigned to the genus Grammysia, is revised. Cuneamya catilloides is an important element of the Modiolopsis Community Group in the Letná Formation. The genus Grammysia very probably does not occur in the Ordovician of Bohemia and is restricted to the Silurian and Devonian strata. Cuneamya catilloides with strong commarginal costae was probably an infaunal filter feeder. Cuneamya is a cosmopolitan genus, occurring on Avalonia, Baltica, Laurentia, Perunica and West Gondwana.
\end{abstract}

Key words: Cuneamya, Late Ordovician, Bohemia, systematics, palaeoecology, palaeobiogeography

Received: April 17, 2019| Accepted: May 29, 2019| Issued: August 29, 2019

\section{Introduction}

The bivalves from the Ordovician rocks of Bohemia are primarily known through the monographs of Barrande (1881) and Pfab (1934). Růžička and Prantl (1960) designated some lectotypes of the bivalves species described by Barrande (1881). Horný (1960) and McAlester (1965) revised the genus Babinka. Krríž (1995) recognised the presence of the genus Coxiconchia in the Middle Ordovician strata of Bohemia and Kříž (1997) briefly summarised the palaeoecology of the Ordovician bivalves. In the last decade, bivalves from selected stratigraphical intervals were revised (Křriž and Steinová 2009, Steinová 2012 and Polechová 2013). Cuneamya catilloides (Barrande in Perner, 1903) from the Late Ordovician is a peculiar species originally assigned to gastropods which requires special attention. In this contribution, systematics, palaeocology and some palaeogeographic affinities of Cuneamya catilloides (BARRAnde in Perner, 1903) are discussed.

\section{Material and methods}

The material described herein comes partly from the collection of Joachim Barrande housed in the National Museum (prefix NM) and from the collections of Jiří Kříž, Milan Šnajdr and Ondřej Zicha (prefixes JK, MŠ, OZ) stored at the Czech Geological Survey. All figured specimens were coated with ammonium chloride before being photographed (Parsley et al. 2018).

\section{Systematic palaeontology}

R e marks. The classification used by Carter et al. (2011) is adopted here.

\author{
Class Bivalvia Linnaeus, 1758 \\ Subclass Autobranchia GrobBen, 1894 \\ Infraclass Heteroconchia HerTwIG, 1895 \\ Cohort Cardiomorphi FÉrussaC, 1822 \\ Subcohort Cardioni Férussac, 1822 (= Euheterodonta \\ Giribet et Distel, 2003) \\ Family Grammysiidae MiLler, 1877 \\ Subfamily Cuneamyinae Morris, \\ Dickins et Astafieva-Urbajtis, 1991
}

Genus Cuneamya Hall et Whitfield, 1875

Ty pe species. By original designation, Cuneamya miamiensis HALL et WhITFIELD, 1875 from the Upper Ordovician of the United States.

Remarks. The type species of Cuneamya HaLl et Whitfield, 1875 was depicted by Pojeta (1971) although the locality and stratigraphical horizon remained unknown. Generally, the type material is poorly preserved. Ulrich and Scofield (1894) related the genus Cuneamya to Grammysia DE VerneulL, 1847. Grammysia shows a pronounced radial sulcus in sculpture but Cuneamya possesses only commarginal lines without a radial sulcus. Both genera Grammysia and Cuneamya are reported from Ordovician and Silurian strata. Moreover, Grammysia is also known from Devonian strata. Ordovician Cuneamya is also known from the Late Ordovician of Argentina (Sánchez 1990), Canada (Foerste 1924), Norway (Soot-Ryen and Soot-Ryen 1960, Toni 1975), Sweden (Dahlqvist et al. 2010) and the United Kingdom (Hurst 1979, Lockley 1980). 
Cuneamya catilloides (Barrande in Perner, 1903) Pl. 1, Figs 1-6, Pl. 2, Fig. 3a-d, Pl. 3, Figs 1-8

1903 Grammysia catilloides Barr. sp.; Perner, pl. 43, figs 24-30. 1907 Grammysia? catilloides Barr. sp. (= Capulus catilloides Barr. M. S.); Perner, pl. 121, figs 19-22.

Lectotype. Designated herein. Specimen NM-L 18100 , internal mould of the shell depicted by Barrande in Perner (1903) on pl. 43, as figs 28-30, re-illustrated here on Pl. 1, Fig. 5a, b.

P a r a l e c t o t y pes. Specimen NM-L 18101, internal mould of the shell figured by Barrande in Perner (1903) on pl. 43, as fig. 27, re-illustrated here on Pl. 1, Fig. 2a, b; specimen NM-L 18102, internal mould of the shell depicted by Barrande in Perner (1903) on pl. 43, as fig. 25, reillustrated here on Pl. 2, Fig. 3a-d.

Type locality and horizon.UpperOrdovician, Sandbian, Letná Formation; Děd near Beroun, the Czech Republic.

M a t e r i a l. Nineteen right valves, four left valves.

Emended diagnosis. Cuneamya with triangular shell and strong shell sculpture composed of numerous commarginal costae and finer lines.

Description. Shell triangular, of medium size, inflated, inequilateral with opisthogyrate umbones closer to the anterior margin. Posterior part of the shell larger than the anterior part. Anterior and posterior margin convex, steeply sloping to the ventral part. Umbones pronounced, large, inflated ventral margin rounded. Dorsal margin straight with well developed costae. Hinge unknown, seems to be edentulous. Muscle scars not preserved. Shell sculpture consists of numerous commarginal costae and finer lines, in some specimens radial ribs are presented (NM-L 18098, NM-L 51894).

R e m a r k s . Barrande (1881: pl. 80, box vi, figs 5-8; herein Pl. 2, Fig. 4a-c) depicted "Grammysia" praecox from the locality Dvorce (Devonian, Lochkov Formation). This specimen has a radial sulcus, which seems to be a typical feature of the genus Grammysia. Perner (1903: pl. 43, figs 24-30, 1907: pl. 121, figs 19-23; herein Pl. 1, Figs 1-6, P1. 2, Fig. 3a-d) depicted "Grammysia catilloides" from the Late Ordovician with a note in French: "Barrande voyait dans cette forme un Capulus? catilloides. Dans le régistre de ces planches, nous trouvons cette remarque: "Les fig. 28-29 montrent bien la vue cardinale, qui exclut la possibilité de considérer ce fossile comme bivalve." De plus, il comparait ces formes avec Metoptoma Niobe Bill. Palacoz. Foss., p. 37. et plus tard avec le genre Ambonychia Hall. A notre avis, il est impossible de considérer les formes en question comme des Gastéropodes. Il suffit de jeter un coup d'oeil sur les figures p. ex. Grammysia globosa Hall, Pal. N. York, Vol.5, Part 1. Lamellibranchiata, P1. LXII, fig.10-19 or Ambonychia corrugata Ldstm (Fragm. silur. Pl. $\mathrm{XV}$, fig.1-5) pour se persuader des affinités qui existent entre ce fossile et les bivalves, affinités qu'indique 1'habitus." Translation to English: "Barrande considered this form as Capulus? catilloides. In the list of these plates we found this remark: "The figures 28 and 29 show a cardinal view which excludes the possibility to consider this fossile as a bivalve." Moreover, he compared these specimens with Metoptoma Niobe Bill. Palazoc. Foss. 1, p. 37 and later with the genus Ambonychia Hall. In our opinion, it is impossible to classify these specimens (with reservation) as Gastropods, it is sufficient only to glance at the figures of Grammysia globosa Hall, Pal. N. York, Vol.5, Part 1. Lamellibranchiata, Pl. LXII, fig. 10-19 or Ambonychia corrugata Ldstm (Fragm. silur. Pl. XV, fig.1-5) to find affinities which existed between these bivalve fossils and accomodate these specimens in bivalves."

Perner (1903) also compared specimens of Grammysia with Paracyclas? libens (pl. 3, figs 27-29; herein Pl. 2, Figs 1, 2a, b) from the locality Butovice (upper Silurian, Kopanina Formation). However Paracyclas? libens has the umbo in a central position and sculpture is different, composed of commarginal lines. Cuneamya catilloides is probably restricted to the Late Ordovician.

Generally, Cuneamya catilloides seems to be different from the other species of Cuneamya in the triangular shape of the shell. Cuneamya miamiensis Hall et WhitFIELD, 1875 from the Late Ordovician of the USA is more elongated with finer commarginal lines. Cuneamya cf. miamiensis is also mentioned by Hurst (1979) from the Late Ordovician of England, but without description and illustration. Cuneamya scapha HALl et Whitfield, 1875 from the Late Ordovician of the USA and the subspecies C. scapha brevior FoERSTE, 1924 from the Late Ordovician of Canada differs in a more elongated and inflated shell. Cuneamya sp. 1 (Toni 1975) from the Late Ordovician of Norway differs in a more elongated shell and pronounced umbo. Cuneamya sp. 2 (Toni 1975) from the Late Ordovician of Norway seems to have a very elongated shell and terminal umbo. Cuneamya sp. 3 (Toni 1975) from the Late Ordovician of Norway has finer commarginal lines. Cuneamya multistriata SoOT-RYEN et Soot-Ryen, 1960 from the Late Ordovician of Norway has a more elongated shell, and its commarginal lines are finer than in C. catilloides. Cuneamya? minuta Soot-Ryen et Soot-Ryen, 1960 from the Late Ordovician of Norway differs in having a more elongated shell. Tunicliff (1982) described a specimen, which was left in open nomenclature as Bivalve gen et sp. indet. The specimen is not complete, but it shows affinities to Cuneamya with pronounced commarginal costae. Cuneamya sp. from the Late Ordovician of North Wales (Lockley 1980) is preserved as an internal mould of an articulated specimen. It differs from $C$. catilloides in a more elongated shell and finer commarginal lines. Dahlquist et al. (2010) mentioned the genus Cuneamya from the Late Ordovician (Hirnantian) of Sweden but without description and illustration, a comparison is thus not possible.

O c c urrence. Central Bohemia; Upper Ordovician; Sandbian, Letná Formation (Děd near Beroun); Katian, Vinice Formation (Trubín, Vinice); Katian, Zahořany Formation (Zahořany); Katian, Králův Dvůr Formation (Kosov).

\section{Palaeoecology}

Cuneamya was probably an infaunal burrower. The sculpture on the commarginal ribs and lines is characteristic 
for burrowers. Pronounced sculpture among shallow water burrowing taxa stabilised the animal in the substrate. Moreover, species with well expressed sculpture are considered as slow burrowers (Stanley 1970). The shape of the shell is almost circular (in lateral view), which indicates the direction of burrowing was vertically downwards (Stanley 1970). Cuneamya is relatively abundant in the Modiolopsisdominated bivalve community known from Letná Formation at the locality Děd near Beroun (Drabov). Chlupáč (1965) recognized that material designated as Drabov was derived from at least three different stratigraphical horizons, all of them belong to the upper part of the Letná Formation. The Cuneamya material probably comes from the first horizon, called "the oldest fossil-rich layer" by Chlupáč (1964). How it was shown e.g. by Babin (1966) and Babin and Hamman (2001), the Modiolopsis species had been dominant in many communities since the Early Ordovician. Kříž and Steinová (2009) characterised the Modiolopsis Community Group which inhabited shallow, high energy and sandy nearshore environments. Other occurrences of Cuneamya catilloides in strata above the Letná Formation are scarce; the determination of this species in off-shore fine grained siliciclastics and shales is also complicated by deformation of the shell.

\section{Palaeogeographic affinities}

During the Early and Mid Ordovician, bivalves were restricted mainly to low-latitude basins around Gondwana in the southern hemisphere (Cope and Krríž 2014). Late Ordovician bivalves are more dispersed, which also confirms the occurrences of the genus Cuneamya from the Late Ordovician strata of Avalonia, Baltica, Laurentia, Perunica and West Gondwana.

\section{Conclusions}

(1) The Late Ordovician bivalve Grammysia catilloides is newly described as Cuneamya catilloides, lectotype and paralectotypes are designated and newly illustrated herein.

(2) Pronounced commarginal ribs and the shape of the shell (nearly circular) are characters indicating that this species was, most probably, an infaunal burrower. Cuneamya catilloides is the most abundant species in the shallow water Modiolopsis Community Group known from the Letná Formation in the locality Děd near Beroun.

(3) Cuneamya is a widespread bivalve genus known from the Late Ordovician of Avalonia, Baltica, Laurentia, Perunica and West Gondwana, clearly supporting the tendency towards cosmopolitism in bivalves during the Late Ordovician.

\section{Acknowledgement}

I would like to thanks the two reviewers, Petr Budil and Štěpán Manda, for their helpful and constructive remarks. This study was supported by the Grant Agency of the Czech Republic, Project No. 18-14575S.

\section{References}

Babin, C. (1966): Mollusques Bivalves et Céphalopodes du Paléozoïque armoricain. - Imprimerie Commerciale et Administrative, Brest, $471 \mathrm{pp}$.

Babin, C., Hamman, W. (2001): Une nouvelle espèce de $M o$ diolopsis (Bivalvia) dans l'Arenig (Ordovicien inférieur) de Daroca (Aragon, Espagne); réflexions sur la denture des bivalves primitifs. - Revista Española de Paleontología, 16: 269-282.

Barrande, J. (1881): Systême silurien du centre de la Bohême. $1^{\text {ère }}$ Partie: Recherches Paléontologiques. Vol. VI. Classe des Mollusques. Ordre des Acéphalés. Planches 49 à 154. - Chez l'auteur et éditeur, Prague, Paris, pls 49-154.

Carter, J. G., Altaba, C. R., Anderson, L. C., Araujo, R., Biakov, A. S., Bogan, A. E., Campbell, D. C., Campbell, M., Chen, J., Cope, J. C. W., Delvene, G., Dijkstra, H. H., Fang, Z., Gardner, R. N., Gavrilova, V. A., Goncharova, I. A., Harries, P. J., Hartman, J. H., Hautmann, M., Hoeh, W. R., Hylleberg, J., Jiang, B., Johnston, P., Kirkendale, L., Kleemann, K., Koppka, J., Kř́žž, J., Machado, D., Malchus, N., Márquez-Aliaga, A., Masse, J.-P., Mc Roberts, C. A., Middelfart, P. U., Mitchell, S., Nevesskaya, L. A., Özer, S., Pojeta, J. Jr., Polubotko, I. V., Pons, J. M., Popov, S., Sánchez, T., Sartori, A. F., Scott, R. W., Sey, I. I., Sinorelli, J. H., Silantiev, V. V., Skelton, P. W., Steuber, T., Waterhouse, J. B., Wingard, G. L., Yancey, T. (2011): A synoptical classification of the Bivalvia (Mollusca). - Paleontological Contributions, 2011(4): 1-47.

Cope, J. C. W., Kř́žž, J. (2014): The Lower Palaeozoic palaeobiogeography of Bivalvia. - Memoirs, Geological Society of London, 38: 221-241. https://doi.org/10.1144/M38.16

Chlupáč, I. (1965): Xiphosuran Merostomes from the Bohemian Ordovician. - Sborník geologických věd, Paleontologie, 5: 7-38.

Dahlqvist, P., Harper D. A. T., Wickström, L. (2010): Late Ordovician shelly faunas from Jämtland: palaeocommunity development along the margin of the Swedish Caledonides. - Bulletin of Geosciences, 85(3): 505-512 https://doi.org/10.3140/bull.geosci.1175

Foerste, A. F. (1924): Upper Ordovician faunas of Ontario and Quebec. - Memoir, Geological Survey of Canada, 138(121): 1-99. https://doi.org/10.4095/100856

Hall, J., Whitfield, R. P. (1875): Fossils of the Hudson River Group (Cincinnati formations). - Report, Geological Survey of Ohio, 2: 67-161, pls 1-5.

Horný, R. (1960): On the phylogeny of the earliest pelecypods (Mollusca). - Věstník Ústředního ústavu geologického, 35: 479-482.

Hurst, J. M. (1979): Evolution, succession \& replacement in the type Caradoc (Ordovician) benthic faunas of England. - Palaeogeography, Palaeoclimatology, Palaeoecology, 27: 189-246. https://doi.org/10.1016/0031-0182(79)90104-4

Kříž, J. (1995): Coxiconchia Babin, 1966 from the Llanvirn of the Prague Basin (Bivalvia, Ordovician, Bohemia) 
and the function of some "accessoric" muscles in recent and fossil Bivalvia. - Věstník Českého geologického ústavu, 70(2): 45-50.

Křiž, J. (1997): Poznámky k paleoekologii mlžů ordoviku pražské pánve [Remarks to palaeoecology of the Prague Basin Ordovician Bivalvia]. - Zprávy o geologických výzkumech v roce 1996: 168-172. (in Czech)

Kříž, J., Steinová [= Polechová], M. (2009): Uppermost Ordovician bivalves from the Prague Basin (Hirnantian, Perunica, Bohemia). - Bulletin of Geosciences, 84(3): 409-436. https://doi.org/10.3140/bull.geosci.1141

Lockley, M. G. (1980): The Caradoc faunal associations of the area between Bala and Dines, North Wales. - Bulletin of the British Museum of Natural History (Geology), 33(3): 165-235.

McAlester, A. L. (1965): Systematics, affinities and life habits of Babinka, a transitional Ordovician lucinoid bivalve. - Palaeontology, 8(2): 231-246.

Parsley, R. L., Lawson, M. H., †Pojeta, J., Jr. (2018): A practical and historical perspective on the how and why of whitening fossil specimens and casts as a precursor to their photography. - Fossil Imprint, 74(3-4): 237-244. https://doi.org/10.2478/if-2018-0016

Perner, J. (1903): Systême silurien du centre de la Bohême par Joachim Barrande. $1^{1}$ èr partie: Recherches Paléontologiques, Vol. IV. Gastéropodes, Tome I ${ }^{\text {er }}$ Texte (Patellidae et Bellerophontidae) et Planches 1 à 89. - Prague, 164 pp. +89 pls.

Perner, J. (1907): Systême silurien du centre de la Bohême par Joachim Barrande. $1^{\text {èr }}$ partie: Recherches Paléontologiques, vol. IV. Gastéropodes, Tome II. Texte et Planches 90-175. - Prague, 380 pp. + pls 90-175.

Pfab, L. (1934): Revision der Taxodonta des böhmischen Silurs. - Palaeontographica, Abteilung A, 80: 195-253.

Polechová, M. (2013): Bivalves from the Middle Ordovician Šárka Formation (Prague Basin, Czech Republic). - Bulletin of Geosciences, 88(2): 427-461. https://doi.org/10.3140/bull.geosci.1426
Růžička, B., Prantl, F. (1960): Genotypy některých Barrandových rodů staroprvohorních mlžů (Pelecypoda) [Types of some Barrande's Pelecypods (Barrandian)]. - Časopis Národního muzea, Oddíl př́rodovědný, 1960(1): 48-55. (in Czech with English summary)

Sánchez, T. M. (1990): Bivalvos del Ordovícico medio-Tardio de la Precordillera de San Juan (Argentina) [Middle-Late Ordovician bivalves of the Precordillera of San Juan (Argentina)]. - Ameghiniana, 27(3-4): 251-261. (in Spanish)

Soot-Ryen, H., Soot-Ryen, T. (1960): The middle Ordovician of the Oslo region, Norway. Pelecypoda. - Norsk Geologisk Tidsskrift, 40(2): 81-122.

Stanley, S. M. (1970): Relation of shell form to life habits of the Bivalvia (Mollusca). - Memoir, Geological Society of America, 125: 1-296. https://doi.org/10.1130/MEM125-p1

Steinová (= Polechová), M. (2012): Probable ancestral type of actinodont hinge in the Ordovician bivalve Pseudocyrtodonta Pfab, 1934. - Bulletin of Geosciences, 87(2): 333-346. https://doi.org/10.3140/bull.geosci.1330

Toni, R. T. (1975): Upper Ordovician bivalves from the Oslo region. - Norsk Geologisk Tidsskrift, 55: 135-156.

Tunnicliff, S. P. (1982): A revision of late Ordovician bivalves from Pomeroy, Co. Tyrone, Ireland. - Palaeontology, 25: 43-88.

Ulrich, E. O., Scofield, W. H. (1894): The Lower Silurian Lamellibranchiata of Minnesota. - In: Ulrich, E. O., Scofield, W. H., Clarke, J. M., Winchell, N. H. (eds), Final Report of the Geological and Natural History Survey of Minnesota, Vol. 3, Part 2. The Geology of Minnesota, Paleontology. Geological and Natural History Survey of Minnesota, Minneapolis, pp. 475-628. https://doi.org/10.5962/bhl.title.57281

Verneuil, E. de (1847): Note sur le parallélisme des roches des dépôts paléozoïques de l'Amérique Septentrionale avec ceux de l'Europe, etc. - Bulletin de la Société géologique de France, Sér. II, 4: 646-709. 


\section{Explanations to the plates}

\section{PLATE 1}

Cuneamya catilloides (BArrande in Perner, 1903)

1. Zahořany Formation, Zahořany; NM-L 18098. $\mathrm{a}$ - Lateral view on the right valve $\times 1.7 ; b-$ Detail of the umbo $\times 3.1 ; \mathrm{c}-$ Detail of the sculpture on the ventral margin $\times 4.4$.

2. Letná Formation, Děd near Beroun; NM-L 18101, paralectotype. a - Lateral view on the right valve $\times 1.7$; $\mathrm{b}-$ Dorsal view on the right valve $\times 2.2$

3. Letná Formation, Děd near Beroun; NM-L 11887. Lateral view on the right valve $\times 2.5$.

4. Vinice Formation, Trubín; NM-L 18099. a - Lateral view on the right valve $\times 2.5 ; \mathrm{b}-$ Detail of the umbo region $\times 4.5$.

5. Letná Formation, Děd near Beroun; NM-L 18100, lectotype. a - Lateral view on the right valve $\times 3$; $\mathrm{b}-$ Dorsal view on the right valve $\times 2.2$.

6. Letná Formation, Děd near Beroun; NM-L 11886. $\mathrm{a}-$ Lateral view on the right valve $\times 3.5$; $\mathrm{b}-$ Dorsal view on the right valve $\times 2.2$.

\section{PLATE 2}

Paracyclas? libens Barrande in Perner, 1903

1. Kopanina Formation, Butovice; NM-L 5433. Incomplete valve $\times 4.3$.

2. Kopanina Formation, Butovice; NM-L 5434. a - Right valve? $\times 1.9 ; b-$ Dorsal view on the right? valve $\times 4.0$.

Cuneamya catilloides (BARrande in Perner, 1903)

3. Vinice Formation, Vinice; NM-L 18102, paralectotype. $\mathrm{a}-$ Lateral view of the two valves $\times 0.3 ; \mathrm{b}$ - Lateral view of the incomplete valve $\times 1.5$; $\mathrm{c}-$ Lateral view of the left? valve $\times 2.1$; $d-$ Detail of the left? valve $\times 3.1$.

"Grammysia" praecox BARRANDE, 1881

4. Lochkov Formation, Dvorce; NM-L 26369. a - Complete specimen with another bivalve Neklania on one rock sample $\times 1.2 ; \mathrm{b}-$ Right valve with pronounced radial sulcus $\times 2.1$; $\mathrm{c}-$ Detail of the right valve with radial sulcus $\times 3.0$.

\section{PLATE 3}

Cuneamya catilloides (BArrande in Perner, 1903)

1. Vinice Formation, Vinice; NM-L 51901. Lateral view on the right valve $\times 3.0$.

2. Letná Formation, Děd near Beroun; NM-L 51898. Negative of the right? valve $\times 1.75$.

3. Letná Formation, Děd near Beroun; NM-L 51895. Lateral view on the rigt valve $\times 2.5$

4. Letná Formation, Děd near Beroun; NM-L 51899. $\mathrm{a}-$ Lateral view on the right valve $\times 2.2 ; \mathrm{b}-$ Dorsal view on the right valve $\times 4.0$.

5. Letná Formation, Děd near Beroun; NM-L 51900. Lateral view on the right valve $\times 2.1$.

6. NM-L 51897; Letná Formation, Děd near Beroun. $\mathrm{a}$ - Lateral view on the right? valve $\times 2.3$; $\mathrm{b}$ - Dorsal view on the right? valve $\times 3.6$.

7. Vinice Formation, Vinice; NM-L 51896. Lateral view on the left valve $\times 3.4$.

8. Králodvor Formation, Kosov; NM-L 51894. a - Lateral view on the right valve $\times 3.0 ; \mathrm{b}-$ Detail of the sculpture $\times 5.2$. 
PLATE 1

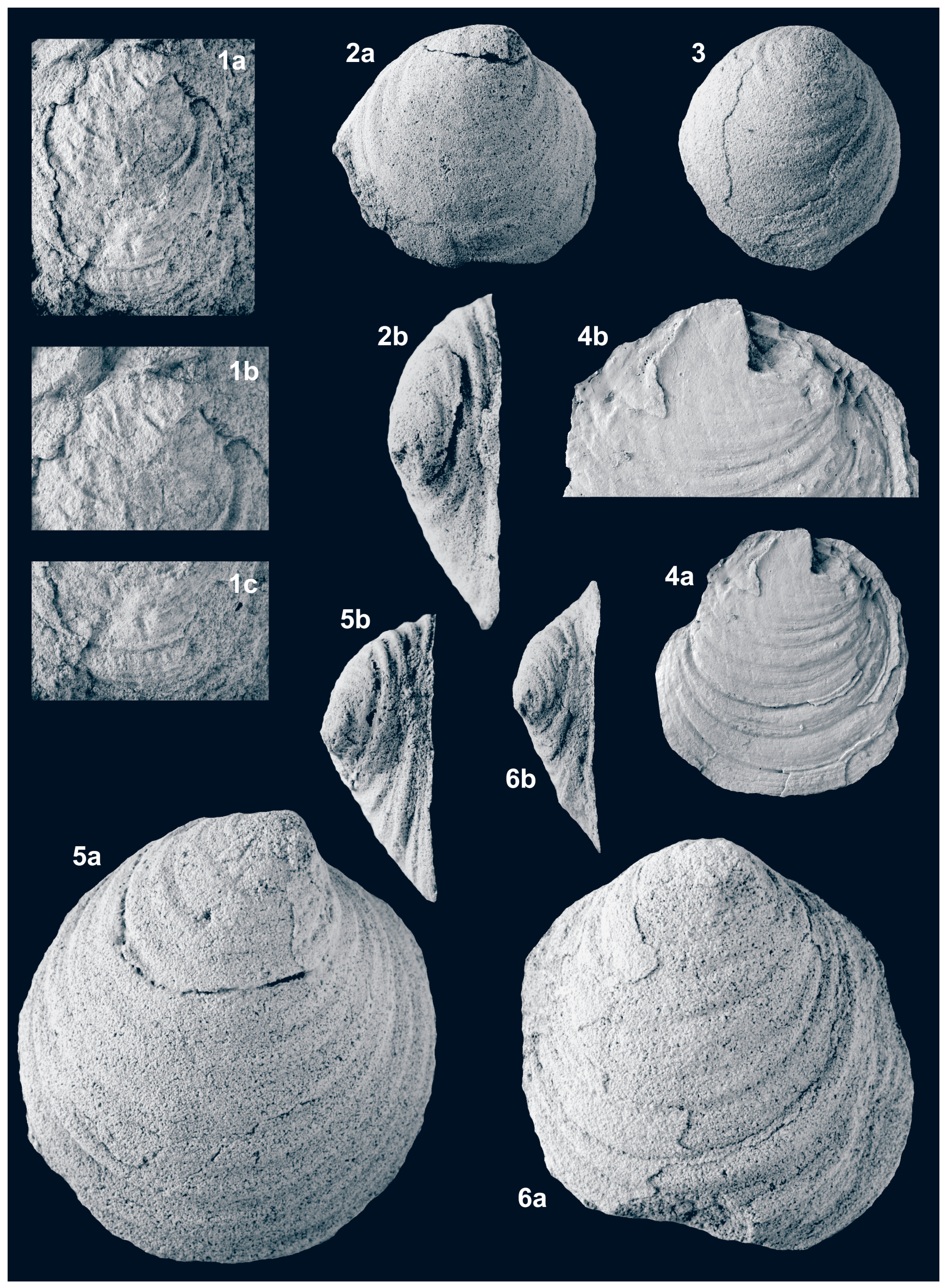


PLATE 2

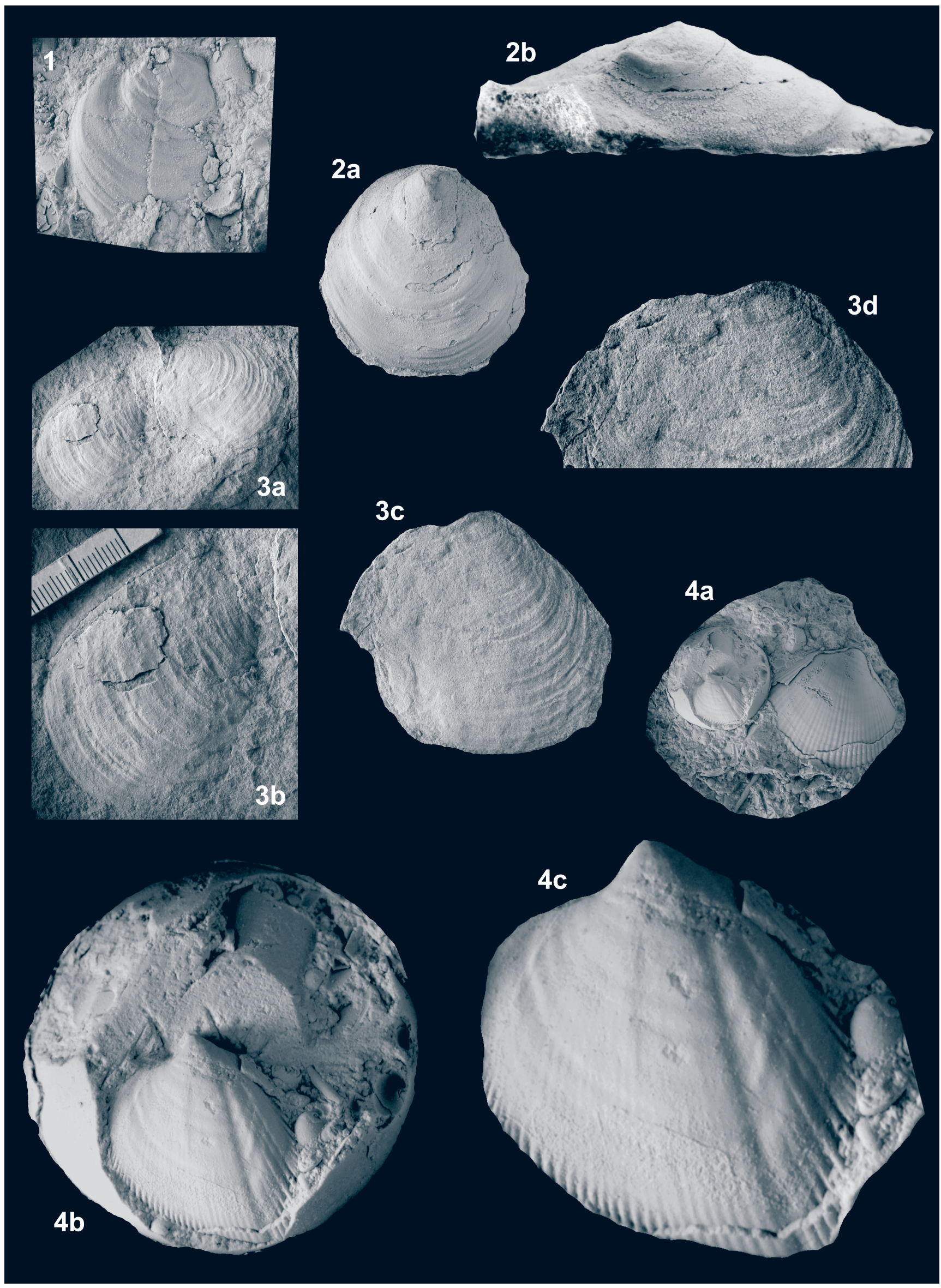


PLATE 3

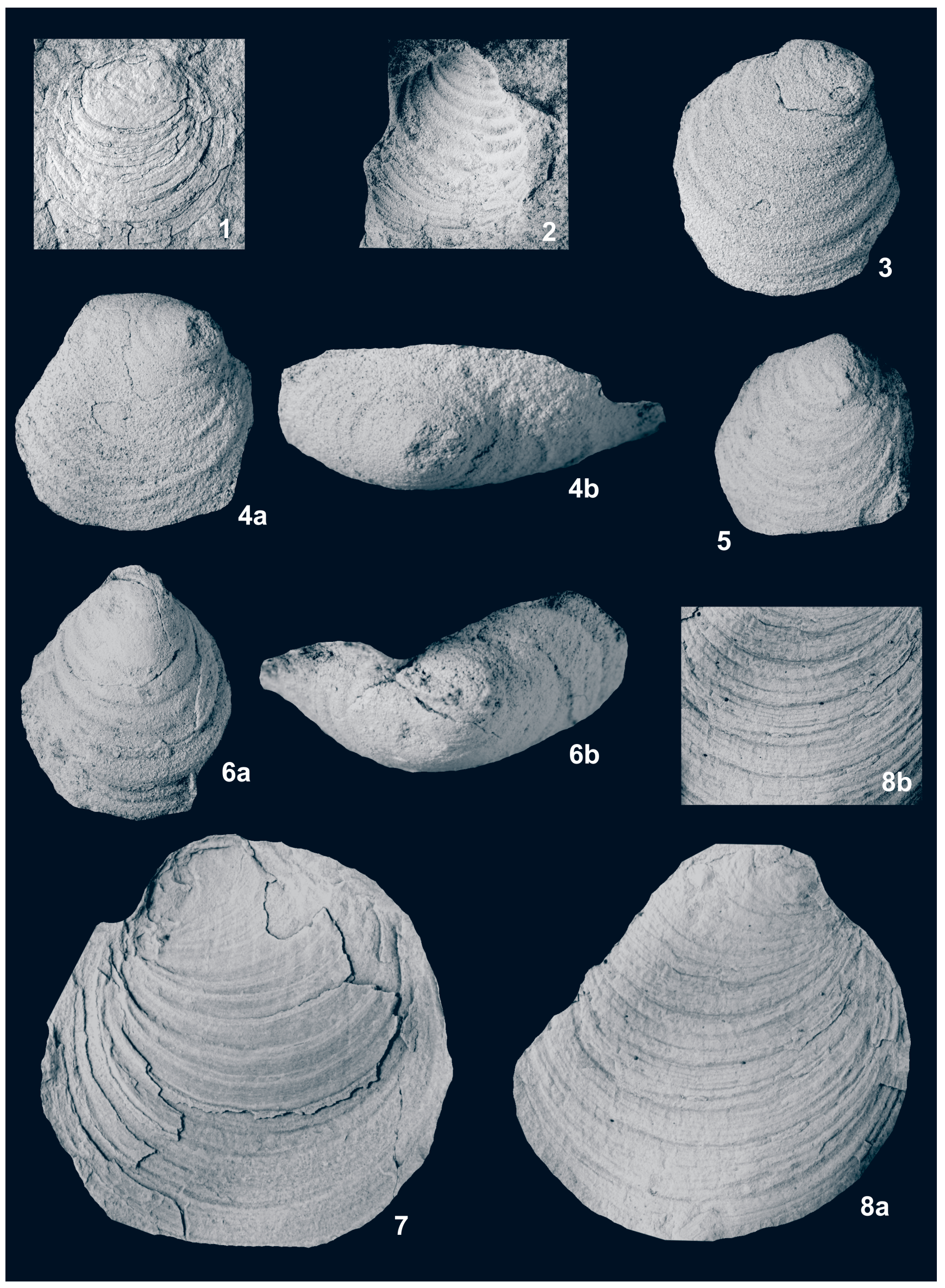

